$$
\begin{gathered}
\text { ミルクホエー共存下におけるセリシンの改質と } \\
\text { そのコーティングポリエステル布帛の特性 }
\end{gathered}
$$

石川県工業試験場繊維生活部 神谷 淳・山本 孝・森 大介

イタリアシルク研究所 C.ペルッツオ・G. M. コロンナ

福井大学大学院工学研究科 堀 照夫

\title{
Modification of Sericin with Milk Whey and Properties of the Coated-polyester Fabric
}

\author{
Jun Kamitani ${ }^{* 1}$, Takashi Yamamoto $^{* 1}$, Daisuke Mori $^{* 1}$, Carlo Peruzzo $^{* 2}$, G.M.Colonna $^{* 2}$, and Teruo Hori ${ }^{* 3}$ \\ ${ }^{* 1}$ Industrial Research Institute of Ishikawa Textile/Life Department, 2-1, Kuratsuki, Kanazawa, Ishikawa \\ 920-8203, Japan \\ ${ }^{* 2}$ La Stazione Sperimentale per la Seta Ufficio di Como, Via Valleggio, 3-22100, Como, Italy \\ ${ }^{* 3}$ University of Fukui, 3-9-1, Bunkyo, Fukui 910-8507, Japan
}

\begin{abstract}
Sericin and milk whey were modified with diisocyanate, toluene-2,4-diisocyanate or hexamethylene diisocyanate as a crosslinking agent, in order to apply for a coating agent of polyester fabrics. The influence of addition of the milk whey was studied. The moisture regain was improved as the ratio of the milk whey to sericin increased at $20^{\circ} \mathrm{C}$ and $65 \%$ RH. Furthermore, we prepared modified sericin/whey coated-polyester fabrics and studied their washing fastness. After 20 times washing, more than half of the modified sericin/whey remained on the coated fabrics.
\end{abstract}

(Received 3 September, 2004; Accepted 7 February, 2005)

\section{1. 緒 言}

絹の有する独特の風合いや優雅な光沢等を再現するた め, その感触などを模倣した各種合繊が開発されている. しかしながら, 近年の衣料素材開発がヘルスケア重視の傾 向となる中で, 絹の持つ特性の中でも特に注目されている 吸湿性や肌への優しさ (生体への適合性) 等を合繊に付与 する技術については未だ充分に達成されていない.また一 方で,イタリアなどの絹織物産地ではその製造工程で大量 に発生する絹廃棄物 (セリシン)の処理が大きな問題とな っている.

これまでにもセリシンをポリエステルなど合瀻へのコ 一ティング材料へ応用する試みがいくつかなされている. 例えば, エチレングリコール [1], ポリウレタン [2] 等 の水溶性樹脂と混合する, あるいはポリエステル織物をあ らかじめアミン処理してアミノ基を導入し, セリシンを反 応させる [3],瀻維表面をアルカリ処理して粗面化した後 にセリシンをコーティングする [4], セリシンとキトサン の複合体を用いる [5] などが挙げられる. これらの方法 では, セリシンの持つ吸水性等の性質を付与することはで きるが, 洗濯堅ろう度が低い場合も多く,さらにコーティ ングの際に樹脂を用いる場合にはその有害性も懸念され
る.

一方で, 堀らは食品等に利用されている牛乳から得られ る天然タンパクの 1 種であるミルクホエーなどをジイソ シアネートと反応させることで疎水性を与え, 分子量を増 大させることで有機溶媒（ジメチルホルムアミド, ジメチ ルアセトアミド）に溶解させることに成功している [6-8].

そこで我々はセリシンをジイソシアネートで架橋する ことで疎水性を付与し, 高分子量化することでポリエステ ルヘのコーティング剤として利用することを検討してき た [9-12].

本報告では, セリシンを架橋する際により親水性の高い ミルクホエーを添加し, 同時に反応させて得られる改質セ リシンーのミルクホエーが及ぼす影響を検討した.さらに, 改質セリシン/ホエーをポリエステル布帛へコーティング し, 布帛の水分率, 耐洗濯性等を調べた。

\section{2. 実験方法}

\section{1 試薬}

セリシンはイタリア Pecco \& Malinverno 社から購入し た.このセリシンは助剤を用いずに高温の水のみで絹を精 
練して得たもので, 界面活性剂等の不純物を含まない. ミ ルクホエーは明治乳業株式会社から購入し, その組成は夕 ンパク質（89\%以上），炭水化物（2\%以下），脂質（1\% 以下), 灰分（2\%以下）, 水分（6\%以下）であった。架 橋剤である TDI (toluene-2,4-diisocyanate) と HDI (hexamethylene diisocyanate) は東京化成工業株式会社 から購入した. ポリエステル布帛は財団法人日本規格協会 が販売している染色堅ろう度試験用添付白布を用いた. 他 の試薬は市販されているものを精製せず用いた.

\section{2 セリシンの改質反応}

セリシンのジイソシアネートによる改質は堀らの方法 に従った [6]. ジイソシアネートに TDI と HDI の 2 種類を 用いた. その分子構造をFig. 1 に示す.
TDI

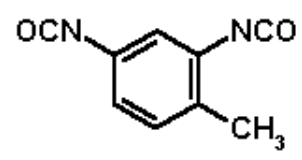

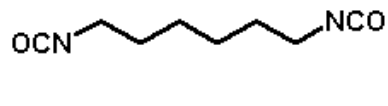

HDI
Fig. 1 Structures of diisocyanates.

ミルクホエーはセリシン重量に対して，33 または 50\% の割合で添加し, 反応させた. 典型的な反応例を以下に示 す.

水 $35 \mathrm{~L}$ にセリシン $800 \mathrm{~g}$ とミルクホエー $800 \mathrm{~g}$ を加え, こ の溶液の $\mathrm{pH}$ を $6 \mathrm{~N}$ 水酸化ナトリウム水溶液を用いて 12 に 調整した.さらに TDI430g を含むクロロホルム $4 \mathrm{~kg}$ を加え, $45^{\circ} \mathrm{C}$ で 2 時間反応させた. 反応中, 溶液の $\mathrm{pH}$ は低下する ので, $6 \mathrm{~N}$ 水酸化ナトリウム水溶液を加えることで $\mathrm{pH}$ を 12 に保った. 反応後, 室温で一晚放置した後, クロロホルム 層と沈殿を除去した. さらに, 遠心分離（9000 rpm）を 2 時間行い, 完全にクロロホルム層と沈殿を取り除いた. 残 った水層の $\mathrm{pH}$ を $2 \mathrm{M}$ クエン酸水溶液で 3.2 に調整した. 遠心分離 (9000rpm) とデカンテーションで余分な水分を 除去し, 生成した改質セリシン/ホエーを水を含むぺース ト状で得た. 収量等を Table 1 内の entry 3 に示す。

Table 1 The conditions and yield of modification of sericin/whey.

\begin{tabular}{ccccc}
\hline entry & diisocyanate & $\begin{array}{c}\text { sericin } \\
(\mathrm{g})\end{array}$ & $\begin{array}{c}\text { whey } \\
(\mathrm{g})\end{array}$ & \multicolumn{1}{c}{$\begin{array}{c}\text { yield } \\
(\mathrm{g})\end{array}$} \\
\hline 1 & TDI & 1200 & $0(0)^{\mathrm{a}}$ & $730(61)^{\mathrm{b}}$ \\
2 & TDI & 1000 & $500(33)^{\mathrm{a}}$ & $1370(91)^{\mathrm{b}}$ \\
3 & TDI & 800 & $800(50)^{\mathrm{a}}$ & $1220(76)^{\mathrm{b}}$ \\
4 & HDI & 1500 & $0(0)^{\mathrm{a}}$ & $1120(75)^{\mathrm{b}}$ \\
5 & HDI & 1000 & $500(33)^{\mathrm{a}}$ & $1140(76)^{\mathrm{b}}$ \\
6 & HDI & 800 & $800(50)^{\mathrm{a}}$ & $1220(76)^{\mathrm{b}}$ \\
\hline
\end{tabular}

a) percentage of whey of total protein weight,

b) percentage of recovery protein after modification.
また,他のセリシンの改質条件を同様に Table 1 に示す. ミルホエーを添加すると得られる改質セリシンの収率は 向上した．特に entry 2 におけるミルクホエーを 33\%含む 反応系では, 90\%以上のタンパク質が回収された。

2.3 改質セリシン/ホエーの溶解性測定

水またはジメチルホルムアミド（DMF）に対して 0.025 wt\%の改質セリシン/ホエーを含むように懸濁液を調 製し、600nm における吸光度を測定することで濁度とした [7-8]. 水懸濁液の pH は塩酸または水酸化ナトリウム水溶 液を用いて調整した。測定装置には紫外可視分光光度計 （日本分光工業株式会社 Ubest-55）を用いた.

\section{4 改質セリシンの表面疎水性測定}

TDI で改質したセリシン, または未改質のセリシンを水 酸化ナトリウム水溶液（0.05N）に溶解し, 3wt\%とした後, リン酸緩衝液（0.1M，pH7）で 100 倍に希釈した. この溶 液 2mL に 1-anil ino-8-naphthalene sulfonate（ANS）溶 液 $(8 \mathrm{mM} / 0.1 \mathrm{M}$ リン酸緩衝液, $\mathrm{pH} 7$ ) $10 \mu \mathrm{L}$ を加え, 室温で 2 時間放置し, 測定試料とした. 測定試料の蛍光強度は蛍光 分光光度計 (Jobin Yvon Horiba SPEX Fluorolog-2 model FL111）を使用し，励起波長 $\lambda_{\mathrm{ex}}=390 \mathrm{~nm}$, 測定波長 $\lambda_{\mathrm{em}}=$ $470 \mathrm{~nm}$ として測定した.

2.5 改質セリシン/ホエーをコーティングしたポリ エステル布帛の調製

$3 \mathrm{wt} \%$ の改質セリシン/ホエー水溶液（pH7）及びDMF 溶液 を調製した。この溶液にポリエステル布帛（約 $30 \times 30 \mathrm{~cm}$ ) を 5 分間浸せきし, $120^{\circ} \mathrm{C}$ で 3 分間キュアリングすること によりコーティング布帛を得た. コーティングで布帛に固 着した改質セリシン/ホエーの量は, $105^{\circ} \mathrm{C} て ゙$ 乾燥させたコ 一ティング前後の布帛重量の比較から求めた.

\section{3. 結果と考察}

\section{1 改質セリシン/ホエーの水分率}

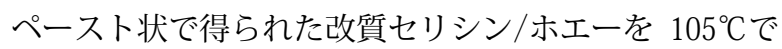
乾燥した後, $20^{\circ} \mathrm{C}, 65 \% \mathrm{RH}$ の䨌囲気下に 8 時間以上放置し, 重量増加率から求めた水分率を Fig. 2 に示す.

すべての改質セリシン/ホエーの水分率は, 反応前と比 較して減少した. この結果は, セリシンに含まれる末端の 親水性基(水酸基及びアミノ基)がジイソシアネートと反 応して減少したことを示唆している．また，HDI より TDI を用いた方が水分率が小さい理由は, 主にベンゼン環を有 する TDI の方が, メチレン鎖を持つ HDI より疎水性が高い ためと考えられる.

さらに, $20^{\circ} \mathrm{C}, 65 \% \mathrm{RH}$ の条件では, ミルクホエーの添加 量が増えるに従い, 水分率は増加した。 


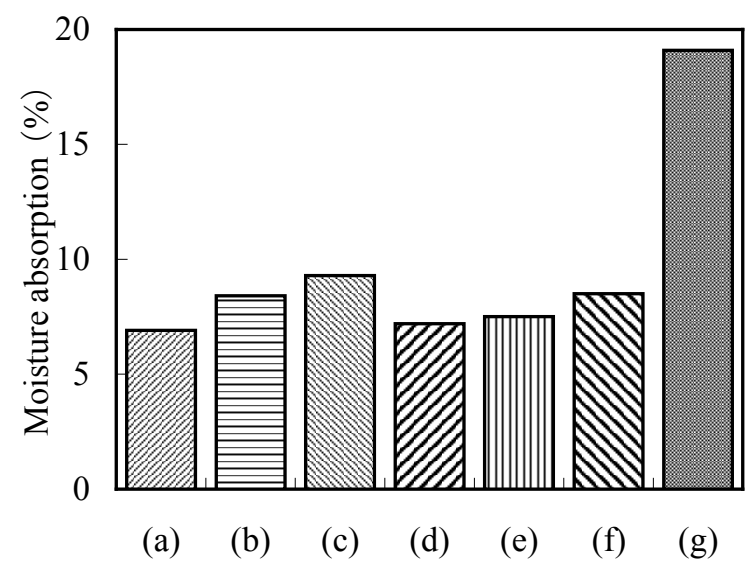

Fig. 2 Moisture regain of modified sericin/whey; (a) TDI + sericin, (b) TDI + sericin $(67 \%)+$ whey $(33 \%),(c)$ TDI + sericin $(50 \%)+$ whey $(50 \%)$, (d) HDI + sericin, (e) HDI + sericin $(67 \%)+$ whey $(33 \%)$, (f) HDI + sericin $(50 \%)+$ whey $(50 \%),(\mathrm{g})$ sericin.

3.2 改質によるセリシンの溶解性及び表面疎水性 の変化

Fig. 3 に TDI で改質したセリシン（Table 1:entry 1）の 水懸濁液 $(0.025 \mathrm{wt} \%)$ の $\mathrm{pH}$ を種々変化させた時の $600 \mathrm{~nm}$ における吸光度を測定した結果を示す.酸性条件下では水 に対する溶解性が低く, 特に $\mathrm{pH}$ が 3 以下ではほとんど不 溶であった。しかしながら, pH 3-4 を越え、中性に近づ くにつれて溶液の濁度は急激に減少し，水溶性を示した。 これは改質セリシンの等電点が 3-4 付近にあることを反 映していると考えられる.

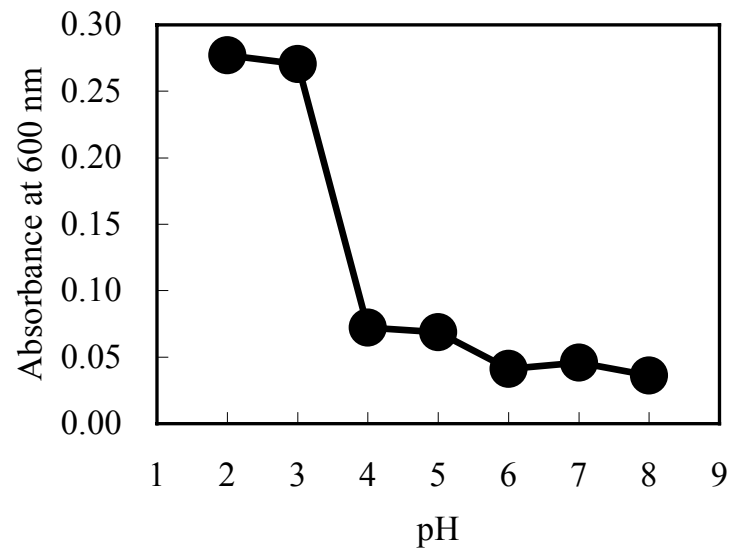

Fig. 3 Turbidity of aqueous dispersion of modified sericin under various $\mathrm{pH}$.

さらにミルクホエーが及ぼす改質セリシンの水溶性へ の影響について調べるために, 同様に濁度を測定した. Fig. 4 は改質セリシン/ホエー水懸濁液（0.6wt\%, pH7）の $600 \mathrm{~nm}$ における吸光度を測定した結果である. ジイソシアネート として TDI, HDI のいずれを用いた場合でも，ミルクホエ
一の添加量が増えるに従い, 水への溶解性は向上した.さ らに, 酸性条件下で沈殿させた, 水に不溶の改質セリシン /ホエーについても DMF 懸濁液を作成し，同様に吸光度を 測定した（Fig. 5). この場合も水に対する場合と同じ傾 向で, ミルクホエーの添加量が増えるに従い, DMFへの溶 解性は上昇した。

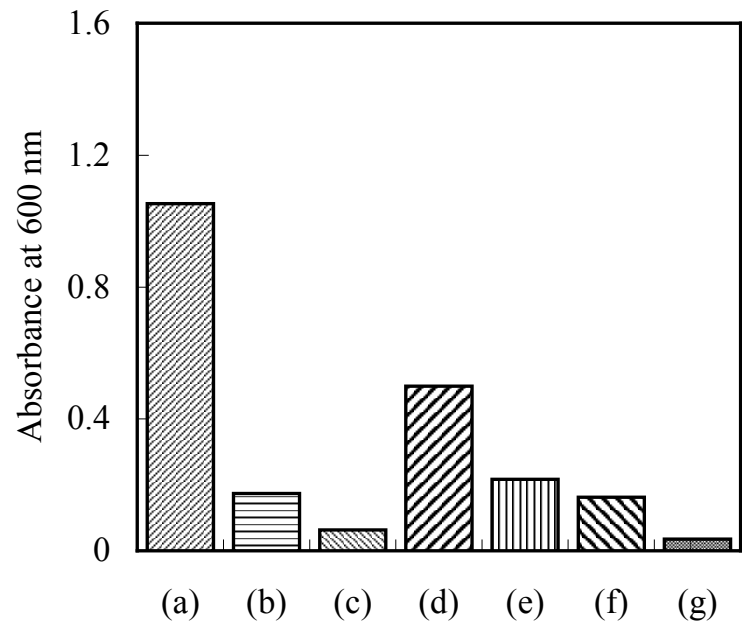

Fig. 4 Turbidity of aqueous dispersion of modified sericin/whey; (a) TDI + sericin, (b) TDI + sericin $(67 \%)+$ whey $(33 \%)$, (c) TDI + sericin $(50 \%)+$ whey $(50 \%)$, (d) HDI + sericin, (e) HDI + sericin $(67 \%)+$ whey $(33 \%)$, (f) HDI + sericin $(50 \%)+$ whey $(50 \%),(\mathrm{g})$ sericin.

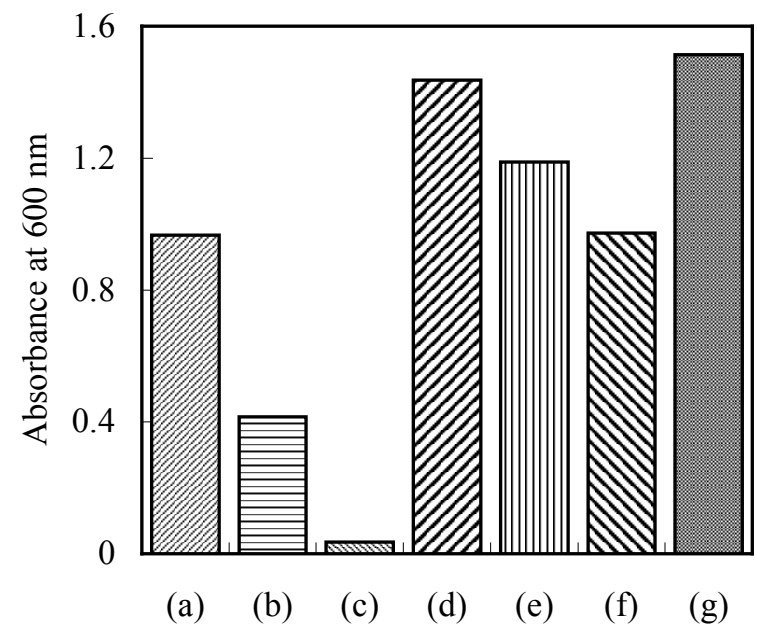

Fig. 5 Turbidity of DMF dispersion of modified sericin/whey; (a) TDI + sericin, (b) TDI + sericin (67\%) + whey (33\%), (c) TDI + sericin $(50 \%)+$ whey $(50 \%)$, (d) HDI + sericin, (e) HDI + sericin $(67 \%)+$ whey $(33 \%)$, (f) HDI + sericin $(50 \%)+$ whey $(50 \%),(\mathrm{g})$ sericin. 
また，改質セリシン（Table 1 :entry 1）の表面疎水性 を蛍光プローブとして ANS を用いて測定した $[8,13,14]$. ANS は水溶液中ではほとんど蛍光を示さないが, タンパク 質の疎水部分など周囲が疎水性の環境になると強い蛍光 性を示す物質である. 結果は Fig. 6 に示すとおり，セリ シンは TDI との反応によって, 表面疎水性が上昇していた. これはセリシン内の親水基であるアミノ基や水酸基が TDI との反応により変化したこと, また, TDI 自体が有す る疎水性がセリシンに付与されたことを示唆しており,水 溶性の結果と一致した。

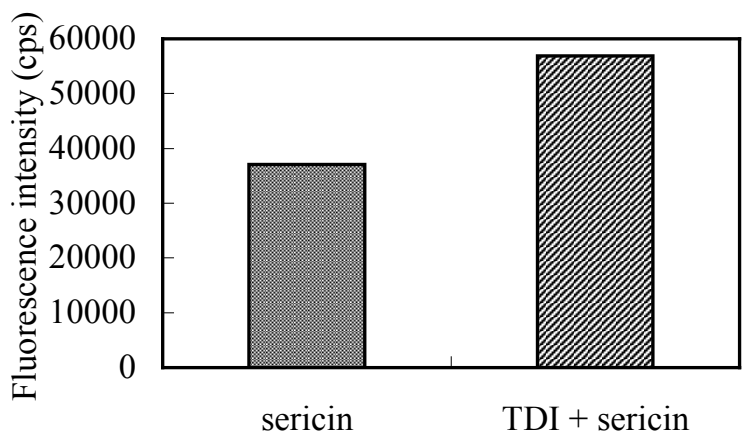

Fig. 6 Surface hydrophobisity of sericin and modified sericin.

\section{3 改質セリシン/ホエーをコーティングしたポリ} エステル布帛の表面状態

改質セリシン/ホエー（Table 1 :entry 3) をコーティ ングしたポリエステル布帛の表面を走查型電子顕微鏡 （Hitachi 製 S-3000N）で観察した結果を Fig. 7 に示す. コーティング前はフィラメント間の隙間が確認できるの に対して, コーティング後は改質セリシンで覆われていた.
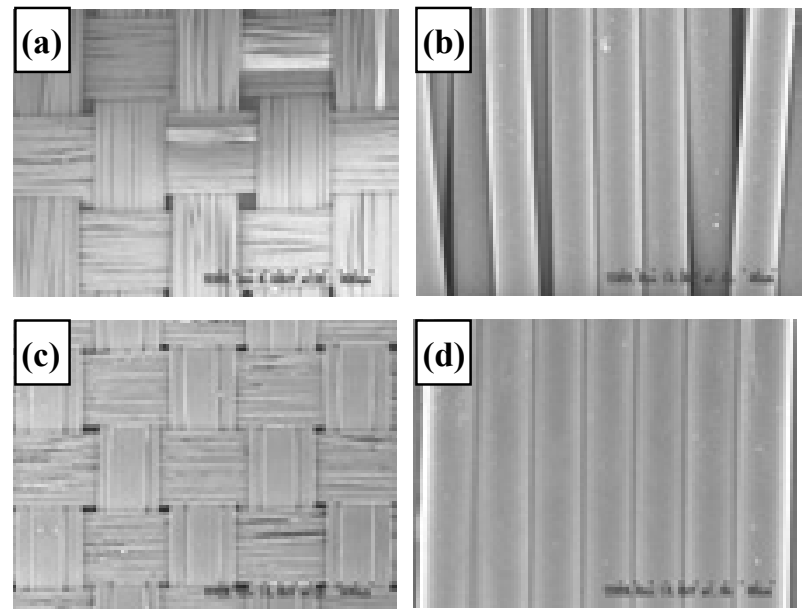

Fig. 7 SEM photographs of polyester fabrics; (a) untreated polyester fabric (100X), (b) untreated polyester fabric (1000X), (c) modified sericin/whey coated polyester fabric (100X), (d) modified sericin/whey coated polyester fabric (1000X).
3. 4 改質セリシン/ホエーをコーティングしたポリ エステル布帛の水分率

改質セリシン/ホエーの布帛への固着量は, コーティン グに用いる溶媒が水の場合で約 4〜 $5 \mathrm{wt} \%$ たたたのに対し て, DMF の場合は 2.1〜9.5 $\mathrm{wt} \%$ と差が見られた（Table 2).

さらに, 各コーティング布帛の吸湿率を $20^{\circ} \mathrm{C}, 65 \% \mathrm{RH}$ で測定した（Table 2). ブランクとして同時に測定した通 常のポリエステル布帛の吸湿率は $0.17 \%$ であり,いずれの 改質セリシン/ホエーをコーティングした場合も, 吸湿率 は改善された. 最も大きな吸湿率をもった布帛は, ミルク ホエーを 33\%含んだ改質セリシンをコーティングした布 帛であり, 約 $1 \%$ の吸湿率だった。

また, 改質セリシン/ホエー粉末はミルクホエーの割合 が増加するに従い, 水分率は向上したが, コーティング布 帛ではこの傾向が見られなかった.この主な原因として改 質セリシン/ホエーの布帛への固着量が影響していると考 えられる.

Table 2 Increase in weight and moisture regain of the modified sericin/whey-coated fabrics.

\begin{tabular}{|c|c|c|c|c|}
\hline \multirow[b]{2}{*}{ entry $^{b}$} & \multicolumn{2}{|c|}{ weight gain $(\%)$} & \multicolumn{2}{|c|}{ moisture regain $^{\mathrm{a}}(\%)$} \\
\hline & water $^{\mathrm{c}}$ & $\mathrm{DMF}^{\mathrm{d}}$ & water $^{\mathrm{c}}$ & $\mathrm{DMF}^{\mathrm{d}}$ \\
\hline 1 & 5.0 & 5.5 & 0.77 & 0.79 \\
\hline 2 & 4.4 & 9.5 & 0.70 & 0.95 \\
\hline 3 & 4.3 & 4.2 & 0.33 & 0.57 \\
\hline 4 & 4.5 & 3.0 & 0.83 & 0.47 \\
\hline 5 & 4.3 & 2.1 & 0.75 & 0.43 \\
\hline 6 & 4.0 & 3.4 & 0.44 & 0.36 \\
\hline
\end{tabular}

a) Moisture regain of untreated fabric was $0.17 \%$, b) see Table 1, c) modified sericin/whey-coated fabrics made from aqueous solution, d) modified sericin/whey-coated fabrics made from DMF solution.

3.5 改質セリシン/ホエーをコーティングしたポリ エステル布帛の洗濯堅ろう度

改質セリシン/ホエーをコーティングした布帛について 市販の中性液体洗剂を用いて, 家庭用洗濯機による洗濯試 験（J IS L0217-103）を行った. また, 洗濯前後の重量減少 率から洗濯堅ろう度を評価した。

水溶液から調製したコーティング布帛は, 一度の洗濯で その大部分が脱落した（Fig. 8)．この中では TDI を架橋 材に用い, ミルクホエーを含まない改質セリシンをコーテ イングした布帛が, 而洗濯性能が最も良かった. しかしこ の系でも洗濯 20 回後では, 95\%以上の改質セリシンが脱 落した。

一方で, DMF 溶液から調製したコーティング布帛は水溶 液から作成したコーティング布帛と比較して, 而洗濯性は 良かった. 特に TDI を架橋材に用い, ミルクホエーを $33 \%$ 含む改質セリシンをコーティングした布帛は, 洗濯 20 回 後でも，半分以上残存していた（Fig. 9). 
DMF 溶液内の改質セリシン/ホエーは，Fig. 3 における 水溶性が低い状態（pH3）であり,一方で $\mathrm{pH} 7$ の水溶液内の 改質セリシン/ホエーは高い水溶性を示している状態であ る.このため, DMF 溶液から調製したコーティング布帛に おけるセリシン/ホエーは, (1) 水への溶解性が小さいこ と，（2）DMF 中では改質セリシン/ホエーの疎水基が分子 外部に配向し, 結果として疎水性であるポリエステルへの 親和性が増加したこと,などが理由で耐洗濯性が良かった と考えられる.

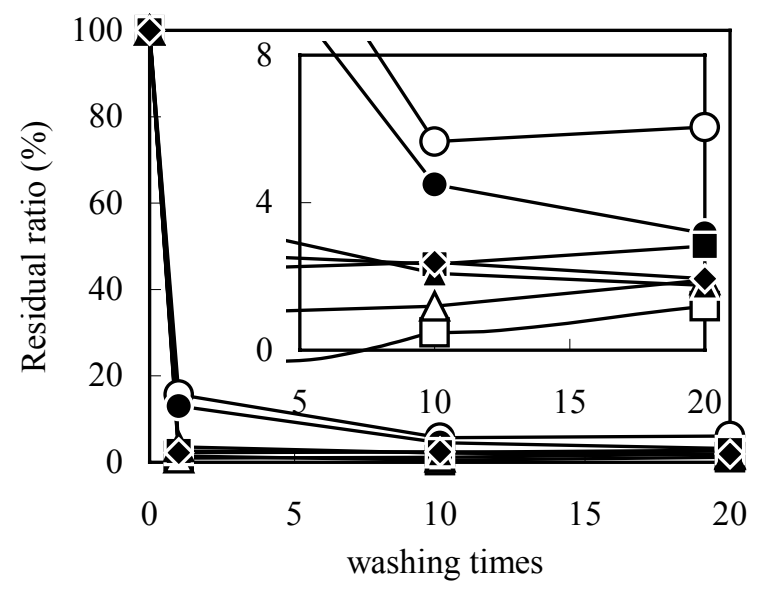

Fig.8 Fastness to washing of modified sericin/whey-coated fabrics made from aqueous solution; $(\bigcirc)$ TDI + sericin, $(\square)$ TDI + sericin $(67 \%)+$ whey $(33 \%),(\triangle) \mathrm{TDI}+\operatorname{sericin}(50 \%)$ + whey $(50 \%),(\bigcirc)$ HDI + sericin, (ם) HDI + sericin $(67 \%)+$ whey $(33 \%),(\boldsymbol{\Delta}) \mathrm{HDI}+$ sericin $(50 \%)+$ whey $(50 \%),(\diamond)$ sericin. The inset shows a magnified view.

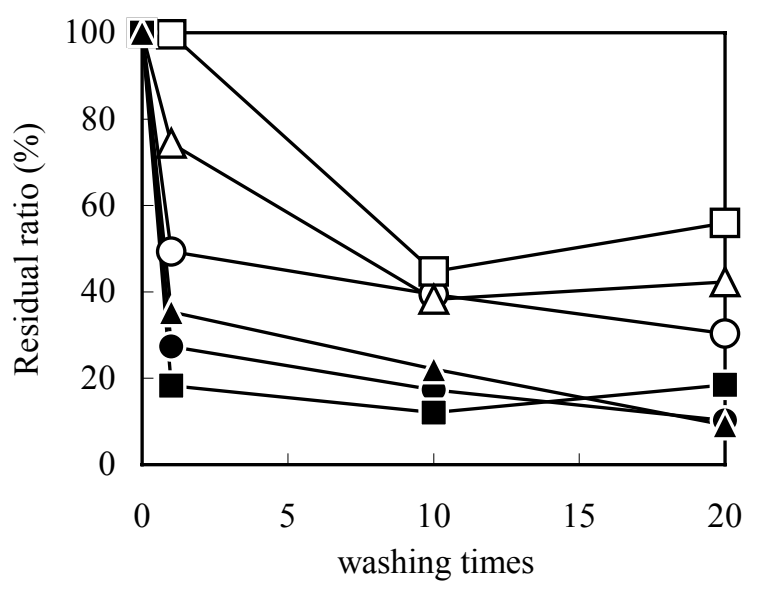

Fig.9 Fastness to washing of modified sericin/whey-coated fabrics made from DMF solution; $(\bigcirc)$ TDI + sericin, $(\square)$ TDI + sericin $(67 \%)+$ whey $(33 \%),(\triangle) \mathrm{TDI}+\operatorname{sericin}(50 \%)$ + whey $(50 \%),(\bigcirc)$ HDI + sericin, $(\boldsymbol{\square}) \mathrm{HDI}+$ sericin $(67 \%)+$ whey $(33 \%),(\boldsymbol{\Delta}) \mathrm{HDI}+$ sericin $(50 \%)+$ whey $(50 \%)$.

\section{4. 結 論}

セリシンをジイソシアネートで架橋反応させる際にミ ルクホエーを共存させると, 収量が最大で $30 \%$ 向上した. また，ミルクホエーの反応割合を増加させると，水にも DMF にも溶解しやすくなることがわかった.

改質セリシン/ホエーをポリエステル布帛にコーティン グすると，標準状態で水分率は最大で約 1\%に向上した.

さらに，改質セリシン/ホエーをコーティングする際の コーティング液の溶媒は, 水よりも DMF を用いた方が, 洗 濯堅ろう度は良かった. 最も良い洗濯堅ろう度を示したの は, ジイソシアネートとして TDI を用い, さらにミルクホ エーを 33\%添加した改質セリシンを DMF 溶液からコーティ ングした布帛であり, 洗濯 20 回後でも半分以上の改質セ リシン/ホエーが残存していた.

\section{謝 辞}

セリシン/ホエーの改質反応に関して協力して頂いた, 大塚化学株式会社に深く感謝いたします。

\section{文 献}

1. Y. Hamaoka, S. Kobayashi, S. Asada, T. Shimizu, and M. Yamasaki, Kyotofu Orimonoshidousyo Kenkyuhokoku, 32, 53, (1998).

2. K. Hayashi, S. Kondo, K. Ejiri, and T. Morisaka, Sen 'i Kakou, 45-9, 13 (1993).

3. P-Z. Ji, T. Igarashi, and T. Hori, Sen'ikogyo Kenkyu -kyoukai Hokoku, 3, 44 (1993).

4. M. Nomura etal, Sen'i Gakkaishi, 48, 305 (1992).

5. A. Nogata, H. Yamada, and M. Nomura, Japan. Pat. H9-031847, Seiren Co.

6. H. Otomo, and K. Shigematsu, J. Food Sci., 1989-7, 42 (1989).

7. K. Yamakoshi, J. Park, and T. Hori, Sen'i Gakkaishi, 51, 544 (1995).

8. J. Park, K. Yamakoshi, and T. Hori, Sen'ikogyo Kenkyukyoukai Hokoku, 6, 39 (1996).

9. T. Yamamoto, Y. Shimbo, G. M .Colonna, B. Marcandalli, and T. Hori, Fiber Preprints, Japan, 55, 127 (2000).

10. J. Kamitani, T. Yamamoto, D. Mori, and T. Hori, Fiber Preprints, Japan, 56, 59 (2001).

11. D. Mori, T. Yamamoto, J. Kamitani, and T. Hori, Fiber Preprints, Japan, 56, 60 (2001).

12. T. Yamamoto, J. Kamitani, D. Mori, and T. Hori, 15 th Sen'i Rengo Kenkyu Happyokai, 15, 100 (2002).

13. A. Kato, and S. Nakai, Biochem. Biophys. Acta., 13, 624 (1980).

14. L. Stryer, J. Mol. Biol., 13, 482 (1965). 